\title{
Pola Asuh Orang Tua Siswa dengan Motivasi Belajar Matematika Tingkat Tinggi pada Masa Pandemi Covid-19
}

\author{
Dhita Nabilah Hendrawan ${ }^{1 *}$, Benny Hendriana ${ }^{2}$ \\ Program Studi Pendidikan Matematika, Universitas Muhammadiyah Prof. DR.Hamka \\ Jalan Tanah Merdeka, Ciracas, Jakarta Timur, Indonesia \\ 1*dhitanabilla26@gmail.com; 2benny_hendriana@uhamka.ac.id
}

Artikel diterima: 24-03-2021, direvisi: 23-09-2021, diterbitkan: 30-09-2021

\begin{abstract}
Abstrak
Pola asuh orang tua merupakan salah satu faktor yang dapat mempengaruhi motivasi belajar anak. Terkait hal tersebut, bimbingan dan didikan dari orang tua akan mempengaruhi motivasi belajar anak, yang pada akhirnya menjadi salah satu penentu keberhasilan belajar. Penelitian ini bertujuan untuk mengetahui bagaimana pola asuh yang diterapkan orang tua pada siswa yang memiliki motivasi belajar matematika tinggi di kelas 8 SMP. Penelitian ini menggunakan metode analisis deskriptif dengan instrumen penelitian berbentuk angket dan wawancara. Subyek penelitian yaitu 38 siswa kelas 8 A dengan fokus 5 siswa pada salah satu SMP Negeri di Tambun Selatan. Hasil penelitian menunjukkan bahwa dari 5 siswa yang mempunyai tingkat motivasi belajar matematika kategori tinggi, terdapat 3 orang tua yang menggunakan tipe pola asuh demokratis dan terdapat 2 orang tua yang menggunakan tipe pola asuh permisif. Kedua pola asuh tersebut dapat digunakan untuk menumbuhkan motivasi belajar matematika yang tinggi pada siswa.

Kata kunci : Covid-19, motivasi belajar, pola asuh.

\section{Parenting Rules on Junior High School Students' High Learning Motivation during the Covid-19 Pandemic}

Abstract

Parenting patterns are one of the factors that can affect children's learning motivation. Parenting. Related to this, the guidance and upbringing of parents will affect children's learning motivation. This study aims to determine how parenting styles are applied by parents to have high motivation to learn mathematics in grade 8 junior high school. This research used descriptive analysis method and the research instrument used questionnaires and interviews. The research subjects were 38 students of grade $8 A$ with a focus of 5 students in one of the public junior high schools in Tambun Selatan. The results of the study from 5 students who had a high level of motivation to learn mathematics showed that 3 parents used the democratic parenting type and there were 2 parents who used the permissive parenting type. Both parenting patterns can be used to grow students' high motivation to learn mathematics.

Keywords: Covid-19, motivation to learn, parenting style.
\end{abstract}




\section{Pendahuluan}

Negara Indonesia saat ini sedang mengalami bencana global, yaitu virus Covid-19 yang menyerang manusia. Kondisi ini mengakibatkan negara Indonesia harus waspada dan melakukan semua kegiatan di rumah untuk mengurangi penyebaran virus Covid-19. Menurut WHO Covid-19 adalah penyakit menular yang disebabkan oleh jenis Corona virus yang baru ditemukan. Corona virus diketahui menyebabkan infeksi saluran nafas pada manusia mulai dari batuk pilek hingga yang lebih kronis seperti Severe Acute Respiratory Syndrome (SARS) dan Middle East Respiratory Syndrome (MERS) (Girma dkk., 2020). Virus ini belum diketahui penyebabnya. Virus corona muncul pertama kali di Wuhan, Tiongkok pada bulan Desember 2019. Virus corona sekarang menjadi sebuah pandemic global yang dapat terjadi di seluruh dunia.

Pandemi Covid-19 membuat semua aspek kehidupan berubah termasuk Pendidikan (Herliandry dkk., 2020; Kurnianto \& Rahmawati, 2020). Hal ini menjadikan pendidikan mengalami tantangan besar. Pemerintah mencoba menyikapi dengan mengeluarkan kebijakan untuk menekan penyebaran virus corona yaitu dengan membuat kebijakan social distancing (humas, 2020; Ristyawati, 2020). Akibat adanya kebijakan ini, cara belajar dari yang dilakukan secara langsung di sekolah, beralih menjadi sistem pembelajaran daring. Pembelajaran daring berdampak pada orang tua, karena pembelajaran daring tidak akan tercapai dengan maksimal tanpa bimbingan dari orang tua (Kurnianto \& Rahmawati, 2020; Yulianingsih dkk., 2020).

Orang tua merupakan lingkungan pertama bagi anak (Kurnianto \& Rahmawati, 2020). Maka dari itu orang tua wajib memberikan pembelajaran pada anak saat dirumah. Banyak orang tua yang keberatan ketika anaknya belajar di rumah, karena anak cenderung bermain meskipun seharusnya waktu tersebut merupakan waktu belajar jika di sekolah. Terkait hal tersebut, menurut penelitian Khasanah dkk., (2020), banyak orang tua yang tidak setuju pembelajaran daring karena kondisi dan teknologi yang tidak mendukung, namun seiring berjalannya waktu, bersedia atau tidak, orang tua harus menerima pembelajaran daring.

Setiap orang tua mempunyai aturan yang berbeda -beda saat membimbing dan mendidik anaknya (Fadhilah dkk., 2019). Hal ini tergantung dari cara pola asuh yang diterapkan keluarga saat mendidik anak. Pola asuh orang tua merupakan salah satu faktor yang dapat mempengaruhi motivasi belajar anak (Febriany \& Yusri, 2013). terkait hal tersebut bimbingan dan didikan dari orang tua akan mempengaruhi motivasi belajar anak saat kegiatan belajar, dan motivasi belajar anak pun akan berpengaruh pada keberhasilan belajar. Hal ini didukung oleh Cahyani dkk., (2020) bahwa keberhasilan proses belajar akan tercapai apabila anak memiliki motivasi belajar yang baik. Menurut Kurnianto \& 
Rahmawati (2020), motivasi belajar berpengaruh dalam kegiatan pembelajaran, sebab apabila siswa belajar tanpa adanya motivasi dari orang tua, maka kegiatan belajar tidak akan maksimal, oleh karena itu siswa harus diberikan motivasi belajar terutama motivasi saat belajar pada mata pelajaran matematika.

Mata pelajaran matematika merupakan mata pelajaran penting di sekolah. Matematika memuat dasar dari berbagai disiplin ilmu karena setiap ilmu pasti memuat matematika di dalamnya (Luritawaty, 2019). Namun disayangkan, pada umumnya matematika dianggap cukup sulit diimplementasikan oleh guru dan siswa dalam pembelajaran, terlebih saat pembelajaran daring. Terkait hal ini, menurut Abidin (2020), matematika merupakan pelajaran yang dirasa sulit menurut siswa, sebab mereka menganggap bahwa matematika harus menghafal rumus-rumus yang begitu banyak. Oleh karena itu pola asuh orang tua begitu penting saat memotivasi anak dalam belajar matematika agar mencapai hasil belajar yang maksimal. Pendapat ini didukung oleh Abidin (2020) bahwa orang tua memiliki peran yang penting pada kegiatan belajar anak di rumah saat pandemi Covid-19.

Pola asuh orang tua adalah interaksi yang dilakukan orang tua dan anak untuk membimbing dan mengarahkan pada nilainilai kebaikan dengan tujuan untuk membangun kepribadian anak, kecerdasan emosional, dan perilaku agar anak kelak dapat bersosialisasi di lingkungan masyarakat (Kamar dkk., 2020; Pucangan, 2017). Menurut Djamarah (Noervadila \& Meiliana, 2019) pola asuh orang tua merupakan kebiasaan orang tua ketika membimbing dan menjaga dari anak lahir sampai anak tumbuh dewasa, dalam membentuk perilaku sesuai norma yang berlaku di lingkungan masyarakat. Dalam melakukan pola asuh, menurut Hedyanti, dkk. (2016), orang tua harus mendidik dan mengarahkan anak agar dapat menumbuhkan minat serta bakat yang ada di dalam diri anak. Berdasarkan definisi dari beberapa ahli, bisa disimpulkan bahwa pola asuh yaitu suatu teknik yang dilakukan orang tua saat membimbing, mengarahkan dan menjaga anak sejak anak lahir hingga remaja untuk menumbuhkan potensi yang dimiliki anak, serta mencapai tujuan yang diinginkan sesuai norma yang berlaku di masyarakat. Terdapat 3 jenis pola asuh menurut Baumrind (Fadhilah dkk., 2019), yaitu pola asuh demokratis, permisif, dan otoriter. Pada pola asuh Demokratis, orang tua membuat aturan dan bersikap tegas namun tetap fleksibel maksudnya memberikan kebebasan untuk mengeksploitasi berbagai hal tetapi tetap dalam pengawasan, untuk mendorong anak mandiri (Nakamnanu, 2015). Sedangkan pada pola asuh permisif, menurut Thalib (Maliki, 2017), orangtua cenderung tidak konsisten dalam menetapkan aturan, mengabaikan perilaku anak yang berakibat anak kurang percaya diri, tidak disiplin dan sulit dalam 
mengambil keputusan. Adapun pada pola asuh otoriter, orang tua mengontrol kehidupan anak. Orang tua pada tipe ini menuntut anak untuk patuh, jika tidak anak akan mendapat hukuman. Pola asuh ini melahirkan anak yang kurang komunikatif, mental cemas dan sulit mengambil keputusan (Nuviantirin, 2018).

Motivasi belajar terdiri dari dua kata yang memiliki arti berbeda. Motivasi merupakan penggerak seseorang untuk melaksanakan sesuatu (Fadhilah dkk., 2019; Yenni \& Sukmawati, 2020). Menurut Cole dan Chan (Dagnew, 2018) motivasi adalah energi pribadi yang diarahkan pada pencapaian tujuan tertentu. Sedangkan belajar menurut Slameto (Cahyani dkk., 2020) yaitu suatu proses perubahan dalam bentuk tingkah laku dan kemampuankemampuan lainnya. Maka jika disimpulkan bahwa motivasi belajar yaitu suatu proses usaha yang mendorong anak untuk dapat mencapai suatu tujuan tertentu. Motivasi belajar dipengaruhi oleh 2 faktor yaitu faktor internal dan faktor eksternal (Cahyani dkk., 2020).

Faktor internal terdiri dari cita-cita (Cahyani dkk., 2020) yang merupakan faktor pendukung dalam meningkatkan semangat belajar. Kondisi siswa juga dapat mempengaruhi motivasi belajar seperti kesehatan dan fisik. Ketika kesehatan dan fisik bekerja dengan maksimal maka akan mempermudah dalam mencapai keberhasilan belajar, dan keadaan psikologis siswa juga mempengaruhi motivasi belajar seperti bakat. Jika bakat diasah terus-menerus melalui belajar maka akan mempermudah dalam mecapai keberhasilan. Sikap juga sangat mempengaruhi motivasi dalam belajar. Ketika siswa belajar dengan suasana senang maka akan mendapatkan hasil yang memuaskan begitu juga sebaliknya. Oleh karena itu dapat disimpulkan dari penjelasan sebelumnya bahwa faktor internal terdiri dari cita-cita, kondisi siswa dan keadaan psikologis siswa.

Salah satu yang Faktor Eksternal yang mempengaruhi motivasi belajar adalah kondisi lingkungan belajar. Kondisi lingkungan belajar yang tentram dan kondusif akan memunculkan semangat siswa, guru, teman, lingkungan sosial masyarakat dan lingkungan sosial keluarga. seperti hubungan antara anak dan orang tua yang harmonis akan sangat mempengaruhi motivasi belajar siswa dan semangat belajar. Maka dari itu dapat disimpulkan bahwa faktor eksternal terdiri dari kondisi lingkungan belajar, lingkungan sosial keluarga, sekolah dan masyarakat.

Motivasi belajar selain dipengaruhi oleh 2 faktor, menurut Sardiman (Danar, 2006) juga memiliki ciri-ciri yaitu: (1) rajin ketika mengerjakan tugas; (2) tegar saat mengalami kesulitan atau tidak mudah putus asa dan tidak merasa cepat puas dengan keberhasilan yang telah tercapai; (3) suka memecahkan masalah dalam soal; (4) mempertahankan pendapatnya jika sudah yakin dengan sesuatu; (5) lebih gemar berlatih mandiri; (6) menunjukkan 
keinginan besar pada berbagai macam permasalahan ketika belajar.

Berdasarkan uraian sebelumnya, terlihat bahwa terdapat hubungan antara pola asuh orang tua dan motivasi yang dimiliki siswa. Hal ini terutama terjadi pada proses pembelajaran dimasa pendemi Covid-19, dimana belajar dilakukan di rumah. Peran orang tua sangat penting untuk memberikan motivasi secara langsung. Orang tua pun dituntut untuk memiliki pola asuh yang baik dalam mendampingi anak selama belajar di rumah (Dewi \& Khotimah, 2020). Dengan demikian, penelitian ini dilakukan untuk mengetahui bagaimana pola asuh orang tua yang dapat membuat motivasi belajar matematika siswa tinggi dimasa pandemi Covid-19. Hal ini dilakukan karena belum adanya penelitian yang berfokus pada jenis pola asuh orangtua yang dapat membuat motivasi belajar siswa menjadi tinggi.

\section{Metode}

Penelitian ini menggunakan pendekatan deskriptif kualitatif. Penelitian dilaksanakan pada salah satu SMP Negeri di Tambun Selatan pada bulan Februari 2021. Instrumen yang digunakan untuk mengumpulkan data berbentuk non tes yaitu angket dan wawancara.

Subyek penelitian adalah 38 siswa dari kelas 8A salah satu SMP Negeri di Tambun Selatan, tetapi fokus penelitiannya diambil 5 siswa beserta orang tuanya, dimana siswa diberikan 37 pernyataan angket melalui google form tentang motivasi belajar matematika. Hasil dari angket tersebut kemudian diambil 5 siswa sebagai sampel dengan skor terbanyak dalam mengisi angket motivasi belajar matematika. Orang tua dari 5 siswa tersebut kemudian di wawancara secara mendalam mengenai pola asuhnya.

\section{Hasil dan Pembahasan}

Hasil penelitian yaitu berupa data dari pengisian angket dan wawancara. Data pertama yaitu diperoleh dari pengisian angket yang dilakukan oleh 38 siswa kelas 8A salah satu SMP Negeri di Tambun Selatan. Dari hasil pengisian angket, peneliti mengambil 5 siswa dengan total skor angket tertinggi. Berikut disajikan data 5 siswa tersebut dalam bentuk tabel.

Tabel 1.

Hasil Skor Angket Tertinggi

\begin{tabular}{lcccc}
\hline No. & $\begin{array}{c}\text { Nama } \\
\text { Siswa }\end{array}$ & $\begin{array}{c}\text { Jenis } \\
\text { kelamin }\end{array}$ & $\begin{array}{c}\text { Total } \\
\text { skor }\end{array}$ & Kode \\
\hline 1 & CNA & Perempuan & 119 & A \\
\hline 2 & DFA & Perempuan & 119 & B \\
\hline 3 & IA & Perempuan & 119 & C \\
\hline 4 & FAA & Laki-laki & 113 & D \\
\hline 5 & RA & Laki-laki & 117 & E \\
\hline
\end{tabular}

Berdasarkan tabel 1. Diketahui bahwa dari 38 siswa yang mengisi angket, terdapat 5 siswa yang mendapat skor motivasi belajar matematika tertinggi yang terdiri atas 3 siswa perempuan dengan total skor yang sama yaitu 119 dan disusul 2 siswa laki-laki dengan masing-masing skor 113 dan 117. Hasil pengisian angket 5 siswa ini memiliki dorongan untuk mencapai suatu tujuan, komitmen danlam belajar, dan optimis. 
Dari hasil pengisian angket 5 siswa dengan skor tertinggi, orang tua dari siswa tersebut kemudian di wawancarai secara mendalam mengenai bagaimana pola asuh yang diterapkan orang tua kepada anaknya. Hasil wawancara dengan orang tua tersebut disajikan pada tabel 2 berikut.

Tabel 2.

Hasil wawancara ola asuh orang tua

\begin{tabular}{|cccc|}
\hline No. & $\begin{array}{c}\text { Nama } \\
\text { Orang tua }\end{array}$ & $\begin{array}{c}\text { Pekerjaan } \\
\text { Orang tua }\end{array}$ & $\begin{array}{c}\text { Tipe } \\
\text { Pola Asuh }\end{array}$ \\
\hline 1 & TMS & Wirausaha & Permisif \\
\hline 2 & AA & $\begin{array}{c}\text { Ibu } \\
\text { Rumah } \\
\text { Tangga }\end{array}$ & Demokratis \\
\hline 3 & S & Serabutan & Demokratis \\
\hline 4 & DI & Wirausaha & Demokratis \\
\hline 5 & TR & $\begin{array}{c}\text { Karyawan } \\
\text { Swasta }\end{array}$ & Permisif \\
\hline
\end{tabular}

Berdasarkan hasil wawancara pada tabel 2., dapat diketahui bahwa dari 5 siswa yang memperoleh hasil skor motivasi belajar matematika tertinggi terdapat tipe pola asuh yang berbeda-beda. Siswa A yang mempunyai motivasi belajar matematika tingkat tinggi, orang tuanya menerapkan pola asuh permisif, yaitu orang tua memberikan kebebasan kepada anaknya. Orang tua siswa A ini tidak pernah mengontrol kegiatan belajar anaknya, yang terpenting anaknya mengikuti pelajaran dengan baik disekolah.

Siswa B yang mempunyai motivasi belajar matematika tingkat tinggi, orang tuanya menerapkan pola asuh demokratis, yaitu dengan memberikan kebebasan dalam berbagai hal, tetapi tetap masih dalam pengawasan orang tua. Gaya komunikasi orang tuanya kepada anak juga terjalin baik dan orang tua nya selalu mendorong anaknya untuk mandiri saat belajar.

Siswa $C$ yang mempunyai motivasi belajar matematika tingkat tinggi, orang tuanya menerapkan pola asuh demokratis, sama hal nya dengan siswa $B$, orang tua siswa $C$ tidak pernah memaksa anak untuk belajar, anak diberikan kebebasan namun masih dalam pengawasan orang tua nya. Orang tua juga selalu membimbing, mendampingi dan mengontrol anaknya Ketika belajar. Siswa C ini memiliki prestasi yang baik juga disekolah.

Siswa D yang mempunyai motivasi belajar matematika tingkat tinggi, orang tuanya menerapkan pola asuh demokratis karena orang tua siswa D memberikan kebebasan kepada anaknya, tetapi tetap dalam pengawasan. Menurut orang tua nya anak laki-laki jika diasuh dengan tipe pola asuh otoriter maka akan semakin berontak. Orang tuanya mengatakan yang terpenting anaknya mengikuti pelajaran dengan baik, dan selalu hadir saat jam pelajaran. orang tua nya memberikan kebebasan untuk mengeksplorasi berbagai hal dan tetap harus komunikasi kepada orang tuanya.

Siswa E yang memiliki motivasi belajar kategori tinggi, orang tuanya menerapkan pola asuh permisif, anak diberikan kebebasan penuh oleh orang tuanya dan tidak pernah mengontrol anaknya. Orang tua nya juga tidak membuat aturan apapun kepada anaknya.

Berdasarkan hasil wawancara seperti diketahui pada tabel 2., terdapat 3 orang 
tua yang menggunakan tipe pola asuh demokratis, ketiga orang tua ini memiliki kesamaan saat mengasuh anaknya yaitu anak diberikan kebebasan namun tetap dalam pengawasan. Orang tua mengontrol anaknya dan mendampingi, serta saling menjaga komunikasi yang baik. Dengan pola asuh tipe demokratis, anak selalu terbuka dengan orang tua, memiliki hubungan yang harmonis dengan teman sebaya dan mampu mengontrol diri sendiri (Maliki, 2017). Pola asuh demokratis menghasilkan anak yang memiliki motivasi belajar kategori tinggi, karena hal yang dilakukan orang tua mempengaruhi motivasi belajar anak (Febriany \& Yusri, 2013).

Berdasarkan tabel 2., juga diketahui bahwa terdapat 2 orang tua yang menggunakan tipe pola asuh permisif. Orang tua siswa A memberikan kebebasan penuh kepada anaknya, tidak pernah mengontrol anak saat belajar, dan tidak perhatian kepada anak. Menurut orang tua dengan tipe permisif, yang paling terpenting untuk anak adalah kesehatan, sedangkan pendidikan bisa dilepas pengawasannya. Orang tua pada tipe ini mengaku tidak pernah mengikuti pembelajaran anaknya karena memang sejak kecil anaknya selalu diajarkan untuk mandiri. Anak dengan tipe pola asuh permisif tetap memiliki motivasi belajar matematika kategori tinggi, karena orang tuanya mengatakan bahwa memang hal tersebut sudah merupakan keturunan. Siswa dapat mengasah kemampuannya sendiri, dan nyaman dengan belajarnya sehingga dapat menyukai berbagai mata pelajaran termasuk matematika. Hal inilah yang menjadikan motivasi belajar matematika siswa dengan pola asuh permisif tergolong kategori tinggi. Walaupun orang tua kurang membimbing anak saat belajar, tetapi siswa sudah terlatih untuk mandiri. Hal ini berbeda dengan hasil penelitian dari (Fadhilah dkk., 2019) yang mengatakan bahwa anak yang diterapkan oleh orang tuanya pola asuh permisif terlihat tidak semangat dan suka menyendiri.

Hal yang sama juga terjadi pada orang tua siswa E yang juga menerapkan tipe pola asuh permisif. Orangtua mengaku tidak memiliki aturan apapun untuk anak, dan juga tidak mengontrol anak. Hal ini dikarenakan orang tuanya merupakan pekerja yang pasti tidak selalu berada dirumah. Menurut orangtua siswa E, yang terpenting adalah anaknya dapat mengikuti pelajaran dengan baik. Anak dengan tipe pola asuh permisif seperti ini juga memiliki motivasi belajar matematika kategori tinggi. Hal ini karena anak diberikan kebebasan penuh dengan memanfaatkan waktu yang ada untuk belajar, walaupun orang tuanya tidak mengontrol anaknya. Kebebasan yang diberikan orangtua dapat membuat anaknya berkembang secara optimal karena bebas berekspresi sesuai keinginan sendiri. Hal ini sejalan dengan pendapat Riswanto (2016) bahwa pengetahuan dan pemahaman yang dilakukan dengan upaya sendiri secara 
bebas dapat membuat anak mencapai aktualisasi diri sehingga mempunyai motivasi yang tinggi.

Berdasarkan hasil uraian sebelumnya, diketahui bahwa pola asuh orang tua berpengaruh dalam meningkatkan motivasi belajar anak. Meskipun hal tersebut tidak berlaku secara mutlak, mengingat terdapat faktor lain yang dapat meningkatkan motivasi belajar, seperti yang dikatakan oleh Cahyani dkk. (2020) bahwa terdapat 2 faktor yang dapat mempengaruhi motivasi belajar yaitu faktor internal (cita-cita, kondisi siswa, dan keadaan psikologis siswa) serta faktor eksternal (lingkungan keluarga, lingkungan sekolah, dan lingkungan masyarakat). Meskipun demikian, pola asuh demokratis dan permisif dapat dijadikan pilihan pola asuh orangtua agar motivasi anak dalam belajar matematika masuk ke dalam kategori motivasi tinggi.

\section{Penutup}

Berdasarkan hasil temuan di lapangan diketahui bahwa terdapat 2 tipe pola asuh yang mampu menumbuhkan motivasi belajar matematika siswa yaitu pola asuh demokratis dan pola asuh permisif. Dari 5 orang tua, pola asuh yang paling dominan diterapkan yaitu pola asuh demokratis, tepatnya diterapkan oleh 3 orang tua. Sisanya sebanyak 2 orang tua menerapkan pola asuh permisif. Meskipun begitu, kedua pola asuh orang tua tersebut sama-sama dapat menjadikan motivasi belajar matematika siswa berada pada kategori tinggi.

Orang tua diharapkan mampu memberikan pola pengasuhan yang tepat kepada anak, memberikan perhatian, mengontrol kegiatan belajar anak dan mendukung kegiatan anak, supaya anak dapat lebih termotivasi dalam belajar matematika. Orangtua juga disarankan mengenal dengan baik karakter anaknya sehingga dapat memberikan pola asuh yang tepat untuk meningkatkan motivasi belajar anak, khususnya motivasi belajar matematia. Guru atau dosen juga disarankan untu dapat menjadi perantara yang baik diantara siswa dengan orang tuanya, diantaranya dengan memberikan informasi bahwa pola asuh orangtua berpengaruh dalam meningkatkan motivasi belajar anak. Penelitian selanjutnya diperlukan untuk menganalisis faktor lain yang mempengaruhi motivasi belajar anak seperti faktor instrinsik.

\section{UCAPAN TERIMA KasIH}

Saya mengucapkan terima kasih kepada bapak Marhalim S.Pd selaku guru pembimbing selama pelaksanaan penelitian pada salah SMP Negeri di Tambun Selatan.

\section{Daftar Pustaka}

Abidin, Z. (2020). Belajar Matematika di Era Covid-19. OSF Preprints, 1-2.

Cahyani, A., Listiana, I. D., \& Larasati, S. P. D. (2020). Motivasi Belajar Siswa SMA pada Pembelajaran Daring di Masa 
Pandemi Covid-19. IQ (IImu AlQur'an): Jurnal Pendidikan Islam, 3(1), 123-140.

Dagnew, A. (2018). The Relationship Among Parenting Styles, Academic Self-Concept, Academic Motivation and Students' Academic Achievement in Fasilo Secondary School, Bahir Dar, Ethiopia. Research in Pedagogy, 8(2), 98-110.

Danar, V., F. (2006). Pengertian Motivasi Belajar. Universitas Negeri Yogyakarta

Dewi, P. A. S. C., \& Khotimah, H. (2020). Pola Asuh Orang Tua Pada Anak Di Masa Pandemi Covid-19. Seminar Nasional Sistem Informasi, 24332441.

Fadhilah, T. N., Handayani, D. E., \& Rofian, R. (2019). Analisis Pola Asuh Orang Tua Terhadap Motivasi Belajar Siswa. Jurnal Pedagogi Dan Pembelajaran, 2(2), 249.

Febriany, R., \& Yusri, Y. (2013). Hubungan Perhatian Orangtua Dengan Motivasi Belajar Siswa Dalam Mengerjakan Tugas-Tugas Sekolah. Konselor, 2(1), 8-15.

Girma, S., Alenko, A., \& Agenagnew, L. (2020). Knowledge and precautionary behavioral practice toward covid-19 among health professionals working in public university hospitals in ethiopia: A web-based survey. Risk Management and Healthcare Policy, 13, 1327-1334.

Hedyanti, W., N., Sudarmiatin, S., \& Utaya, S. Pengaruh Pola Asuh Orangtua
Terhadap Prestasi Belajar IPS Melalui Motivasi Belajar. Jurnal Pendidikan: Teori, Penelitian, \& Pengembangan. 1(5). 865-873.

Herliandry, L. D., Nurhasanah, N., Suban, M. E., \& Kuswanto, H. (2020). Pembelajaran Pada Masa Pandemi Covid-19. JTP: Jurnal Teknologi Pendidikan, 22(1), 65-70.

Humas. (2020). Kebijakan 'Social' dan 'Physical Distancing' Harus Libatkan Tokoh Sampai RT/RW. Setkab.Go.Id.

Kamar, K., Asbari, M., Purwanto, A., Nurhayati, W., Agistiawati, E., \& Sudiyono, R. N. (2020). Membangun Karakter Siswa Sekolah Dasar Melalui Praktek Pola Asuh Orangtua Berdasarkan Genetic Personality. JINoP (Jurnal Inovasi Pembelajaran), 6(1), 75.

Khasanah, D. R. A. U., Pramudibyanto, H., \& Widuroyekti, B. (2020). Pendidikan Dalam Masa Pandemi Covid-19. Jurnal Sinestesia, 10(1), 41-48.

Kurnianto, B., \& Rahmawati, R. D. (2020). Hubunga Hubungan Pola Asuh Orang Tua terhadap Motivasi Belajar Siswa Pada Pembelajaran Daring Masa Pandemi. Seminar Pendidikan Nasional (SENDIKA), 1(1).

Luritawaty, I. P. (2019). Pengembangan Kemampuan Komunikasi Matematik Melalui Pembelajaran Take And Give. Mosharafa: Jurnal Pendidikan Matematika. 8(2). 239-248.

Maliki, M. (2017). Hubungan Pola Asuh Orang Tua terhadap Disiplin Belajar 
Siswa Di SMPN 7 Kubung. Jurnal Konseling Dan Pendidikan, 5(1), 52.

Nakamnanu, Y. (2015). Motivasi dan Hasil

Belajar Siswa. Jakarta: Kresna Bina Insan.

Noervadila, I., \& Meiliana, A. (2019).

Pengaruh Pola Asuh Orang Tua

Demokratis Terhadap Hasil Belajar

Siswa Pada Mata Pelajaran

Matematika Kelas Vii Smpn 1

Situbondo. Jurnal IKA PGSD (Ikatan

Alumni PGSD) UNARS, 7(1), 17.

Nuviantirin, E. W. E. G. (2018). Membentuk

Generasi Emas yang Berkualitas.

Pustaka Media Guru.

Pucangan, K. dkk. (2017). Hubungan antara konsep diri dan pola asuh orang tua terhadap hasil belajar IPA siswa kela $\mathrm{V}$ SD di desa Selat. Jurnal Mimbar PGSD Universitas Pendidikan Ganesha, 5(2), 1-10.

Ristyawati, A. (2020). Efektifitas Kebijakan Pembatasan Sosial Berskala Besar Dalam Masa Pandemi Corona Virus 2019 oleh Pemerintah Sesuai Amanat UUD NRI Tahun 1945. Administrative Law and Governance Journal, 3(2), 240-249.

Riswanto (2016). Pengaruh Model Pembelajaran Kooperatif Tipe Team Assisted Individualization Terhadap Motivasi Belajar Mahasiswa. Mosharafa: Jurnal Pendidikan Matematika. 5(3). 293-304.

Widya Novia Hedyanti, Sudarmiatin, S. U. (2016). Pengaruh Pola Asuh Orang Tua Terhadap Prestasi Belajar IPS melalui
Motivasi Belajar (Studi pada Siswa kelas IV, V,VI gugus 2 Kecamatan Ngantang Kabupaten Malang. Jurnal Pendidikan, 1(1), 865-873.

Yenni, \& Sukmawati, R. (2020). Analisis Kemampuan

Representasi Matematsis Mahasiswa Berdasarkan Motivasi Belajar. Mosharafa: Jurnal Pendidikan Matematika. 9(2). 251262

Yulianingsih, W., Suhanadji, S., Nugroho, R., \& Mustakim, M. (2020). Keterlibatan Orangtua dalam Pendampingan Belajar Anak selama Masa Pandemi Covid-19. Jurnal Obsesi: Jurnal Pendidikan Anak Usia Dini, 5(2), 11381150.

\section{Riwayat Hidup PenUlis \\ Dhita Nabilla Hendrawan.}

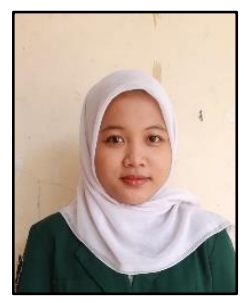

Lahir di Bekasi, 26 Januari 2000. Mahasiswa S1 Pendidikan Matematika Universitas Muhammadiyah Prof. DR. HAMKA.

\section{Benny Hendriana, M.Pd.}

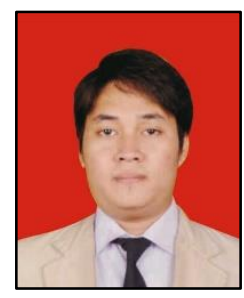

Lahir di Rangkasbitung, 8 Desember 1988. Staff pengajar di Program Studi Pendidikan Matematika Universitas Muhammadiyah Prof. DR. HAMKA. Studi S1 Pendidikan Matematika Universitas Muhammadiyah Prof. DR. HAMKA Jakarta, lulus tahun 2010. Studi S2 Pendidikan Matematika Universitas Negeri Malang, lulus tahun 2013. Sedang menempuh S3 Pendidikan Matematika di Universitas Negeri Semarang. 